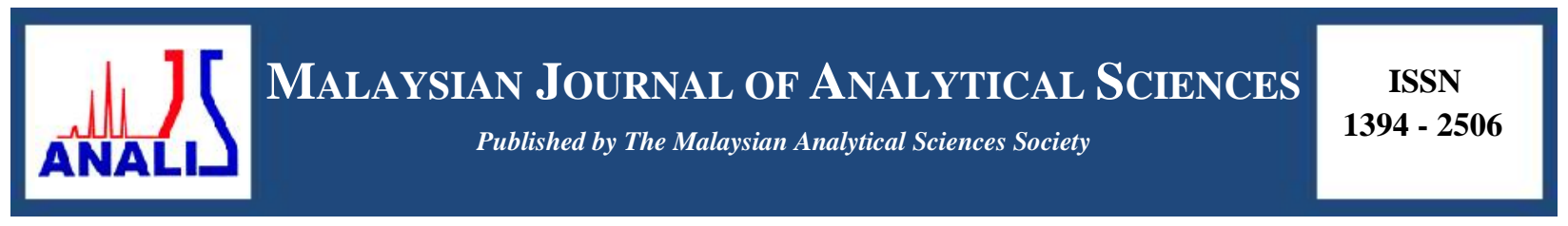

\title{
PRELIMINARY STUDY ON Pd-BASED BINARY CATALYSTS SUPPORTED WITH CARBON NANOFIBER FOR THE ELECTROOXIDATION OF GLYCEROL
}

\author{
(Kajian Awal ke atas Mangkin Berasaskan Pd Disokong dengan Gentian Nano Karbon untuk \\ Pengoksidaan Elektro Gliserol)
}

\author{
Norilhamiah Yahya ${ }^{1 *}$, Siti Kartom Kamaruddinn, ${ }^{2,3}$, Nabila Abdul Karim², Mohd Shahbudin Masdar ${ }^{3}$, \\ Kee Shyuan Loh $^{2}$ \\ ${ }^{I}$ Malaysian Institute of Chemical and Bioengineering Technology, \\ Universiti Kuala Lumpur, 78000 Alor Gajah, Melaka, Malaysia \\ ${ }^{2}$ Fuel Cell Institute \\ ${ }^{3}$ Department of Chemical and Process Engineering \\ Universiti Kebangsaan Malaysia, 43600 UKM Bangi, Selangor, Malaysia \\ *Corresponding author: norilhamiah@unikl.edu.my
}

Received: 28 November 2016; Accepted: 5 February 2017

\begin{abstract}
In this study, Aurum ( $\mathrm{Au}$ ) was used as the second metal in palladium catalyst (Pd) and carbon nanofiber (CNF) as catalyst support for glycerol oxidation. Second metal and catalyst support will help to improve catalytic activity and decrease adsorbed oxidation intermediates species. Carbon nanofiber supported PdAu nanoparticles was synthesized by using trisodium citrate as stabilizing agent and sodium borohydride as reducing agent. Physicochemical characterizations of the catalyst were performed by X-ray Diffraction (XRD), Transmission Electron Microscope (TEM), Field Emission Scanning Electron Microscope (FESEM) and Brunauer-Emmett-Teller (BET) to study the nature of the catalysts. The electrochemical activity for oxidation of glycerol on PdAu/CNF was evaluated in half cell under alkaline media by cyclic voltammetry potentiostat. The densities and mass activity obtained from half-cell analysis were $73.81 \mathrm{~mA} \mathrm{~cm}^{-2} @ 492.04$ $\mathrm{mA} \mathrm{mg}{ }^{-1}, 63.82 \mathrm{~mA} \mathrm{~cm}^{-2} @ 425.44 \mathrm{~mA} \mathrm{mg}^{-1}$ and $55.73 \mathrm{~mA} \mathrm{~cm}^{-2} @ 371.54 \mathrm{~mA} \mathrm{mg}^{-1}$ for PdAu/CNF, Pd/CNF and Au/CNF, respectively in $1 \mathrm{M} \mathrm{KOH}+0.5 \mathrm{M}$ glycerol electrolyte. The electrochemical study, exhibited the superior performance of bimetallic PdAu/CNF catalyst as compared to monometallic Pd/CNF. This indicate that the electronic coupling between $\mathrm{Pd}$ and Au can promote the electrocatalytic activity for glycerol oxidation.
\end{abstract}

Keywords: PdAu, carbon nanofiber, glycerol oxidation, alkaline media

\begin{abstract}
Abstrak
Dalam kajian ini, Au telah digunakan sebagai logam kedua dalam pemangkin paladium dan gentian nano karbon sebagai sokongan pemangkin kepada pengoksidaan gliserol. Logam kedua dan sokongan pemangkin akan membantu meningkatkan aktiviti pemangkin dan mengurangkan perjerapan spesis pertengahan pengoksidaan. PdAu dengan disokong oleh gentian nano karbon telah disintesis dengan menggunakan trisodium sitrat sebagai ejen penstabil dan natrium borohidrat sebagai agen penurunan. Pencirian fizikal-kimia pemangkin telah dijalankan oleh pembelauan sinar-X (XRD), Mikroskop Elektron Penghantaran (TEM), Mikroskop Imbasan Elektron (FESEM) dan Brunauer-Emmett-Teller (BET) untuk mengkaji sifat pemangkin. Aktiviti elektrokimia untuk pengoksidaan gliserol pada PdAu/CNF dinilai dalam sel separuh di bawah media beralkali dengan menggunakan kitaran voltammetri potentionstat. Ketumpatan arus dan berat aktiviti yang diperolehi daripada analisis sel separuh adalah $73.81 \mathrm{~mA} \mathrm{~cm}{ }^{-2} @ 492.04 \mathrm{~mA} \mathrm{mg}^{-1}, 63.82 \mathrm{~mA} \mathrm{~cm}{ }^{-2} @ 425.44 \mathrm{~mA} \mathrm{mg}^{-1}$ dan $55.73 \mathrm{~mA} \mathrm{~cm}{ }^{-2} @ 371.54 \mathrm{~mA} \mathrm{mg}^{-1} \mathrm{masing}$ masing untuk PdAu/CNF, Pd/CNF dan $\mathrm{Au} / \mathrm{CNF}$, dalam $1 \mathrm{M} \mathrm{KOH}+0.5 \mathrm{~m}$ gliserol elektrolit. Kajian elektrokimia, mempamerkan
\end{abstract}


prestasi unggul pemangkin PdAu/CNF berbanding dengan Pd/CNF and Au/CNF. Ini menunjukkan bahawa gandingan elektronik antara Pd dan Au boleh menggalakkan aktiviti elektrokatalitik untuk pengoksidaan gliserol.

Kata kunci: PdAu, gentian nano karbon, oksidasi gliserol, media beralkali

\section{Introduction}

Fuel Cell is one of the alternative energy use to generate electricity without any combustion. Direct Alcohol Fuel Cell in which use methanol and ethanol can be applied in small electronic appliances like hand phone, laptop, camera and lamp. The use of methanol in the fuel cell can be absolutely no doubt, while the use of ethanol has increasing attention among researchers. However, properties of methanol that has high toxicity[1-2] and high volatility of ethanol [3] make both fuels unsuitable as a fuel for the commercialization of fuel cell [4]. One alternative proposed currently is glycerol, to replace methanol in fuel cell application. The growing biodiesel market in Malaysia as Malaysia is the world's largest producer of palm oil will lead to surpass the capacities of glycerol as a by-product. Fuels such as glycerol have drawn an attention because they are renewable from biomass production, less harmful, have high energy density, low vapor pressure, low cost, and easy storage and transportation needs [5-6].

Glycerol is feed at the anode side of fuel cell where the oxidation reaction of glycerol occurs to produce carbon dioxide, electrons and protons. To complete the full reaction in fuel cell, the electrons are pass through the electronic circuit while the proton are permeated through membrane both to cathode side. At the cathode is where the oxygen reduction reaction occurs to complete the cell and produce electricity. However, the oxidation of glycerol quite complicated in which the partial oxidation will produce unwanted products such as glyceraldehyde, 1,3dihydroxyacetone, glyceric acid, hydroxypyruvic acid, tartronic acid, mesoxalic acid, formic acid, ocilic acid and glycolic acid [7, $9-11]$. All these partial oxidation products are not desirable as these products will reduce the performance single fuel cell. Thus, the catalyst selection for the glycerol oxidation is important to increase overall performance fuel cell. The main problem with glycerol oxidation is the potential of generation intermediates species during anodic oxidation of glycerol which might be poison the catalyst surface [12]. Due to this, selection of catalyst is the critical issue in order to increase the activity of glycerol oxidation in anode side and at the same time minimize the cost of the fuel cell itself. Up until now, there are several catalysts use to study the oxidation of glycerol such as platinum. The use of platinum has brought stability issue as another intermediate product of carbon monoxide poisoning the platinum surface by adsorbing too strong on the platinum surface.

Bimetallic electrocatalysts have been used as catalysts in this study, which the purpose is related to the decreased load of the noble metal and combine with secondary metals (normally transition metal). This combination will enhance the electrocatalytic activity of bimetallic mixtures in terms of electrocatalytic activity of bimetallic mixtures in terms of current density and tolerance to the carbon monoxide poisoning effect $[13,14]$. Several previous literatures, reported the effectiveness PdAu bimetallic as the electrocatalyst. Bimetallic containing gold show higher activity and selectivity in helping to oxidize $\mathrm{CO}$ resulting from the reaction intermediate with more efficient even below room temperature in oxidation of ethanol $[15,16,17]$. Therefore, bimetallic palladium-Aurum (PdAu) is used to study the activity of oxidation reaction of glycerol. The Pd-Au is supported to the carbon nanofiber (CNF) so that the catalyst can evenly distributed and to reduce the usage of metal for glycerol oxidation reaction but at the same time have higher catalyst activity. This study will focus on PdAu supported with carbon nanofiber, which believed can give high durability and stability to the catalyst as this bimetallic catalyst has high a tendency to agglomerate. This paper reports the synthesis, physicochemical and electrochemical characterization analysis of $\mathrm{Pd} / \mathrm{CNF}, \mathrm{Au} / \mathrm{CNF}$ and $\mathrm{PdAu} / \mathrm{CNF}$ for glycerol oxidation in half cell.

\section{Materials}

\section{Materials and Methods}

To carry out this research all precursor metal salts and chemicals such as tetrachloroauric acid $\left(\mathrm{HAuCl}_{4} \cdot 4 \mathrm{H}_{2} \mathrm{O}\right)$, palladium chloride $\left(\mathrm{PdCl}_{2}\right)$, trisodium citrate $\left(\mathrm{Na}_{3} \mathrm{Ct}\right)$, sodium borohydride $\left(\mathrm{NaBH}_{4}\right)$, carbon nanofiber, sodium hydroxide and glycerine has been purchased from Sigma-Aldrich (USA). 


\section{Preparation of catalysts using reduction method}

In brief, the synthesized catalyst was modified from the previous study [17], where $0.05 \mathrm{M} \mathrm{PdCl}_{2}$ (Sigma-Aldrich) (in $0.1 \mathrm{M} \mathrm{HCl}$ ) was mixed together with $0.05 \mathrm{M}$ of $\mathrm{AuCl}_{3} \mathrm{HCl} 4 \mathrm{H}_{2} \mathrm{O}$ (Sigma- Aldrich) bring a total solution of $15 \mathrm{~mL}$. The mixed solution was added to some amount of trisodium citrate in drop wise manner. Subsequently, the above solution was added drop-wise to a stirred CNF slurry (isopropanol and deionized water) and stirred for 2 hours. Next, the reduction of the metal precursors is carried out using an appropriate amount of freshly prepared ice-cold sodium borohydride $\left(\mathrm{NaBH}_{4}\right)$ and the solution was stirred overnight at $10{ }^{\circ} \mathrm{C}$. Longer reaction time is needed to allow the sodium borohydride as it has strong reducing abilities to react with metal precursors to form product. The molar ratio of $\mathrm{NaBH}_{4}$ to metal ions was taken as 5:1. The solid was filtered and washed with deionized water several times and dried at $80{ }^{\circ} \mathrm{C}$ overnight.

\section{X-ray diffraction analysis}

XRD is a powerful method used to give the crystallinity of the metal synthesis. The samples data were collected at $2 \theta$ from $20^{\circ}$ to $90^{\circ}$. While FESEM and TEM provide the information about size, size distribution, dispersion and the morphology of various shapes of particles. The morphology of the synthesized catalysts was observed by using FESEM model Zeiss/SUPRA 55VP. The electron microscope specimens have been prepared by dispersing the small amount of catalyst in ethanol and casting it by dropping the solution onto the copper-grids. BET analysis provides on determination the precise specific area evaluation of materials by nitrogen multilayer adsorption measured as a function of relative pressure using a fully automated analyzer. The technique encompasses external area and pore area evaluation to determine the total specific area evaluation to determine the total specific area in $\mathrm{m}^{2} / \mathrm{g}$ yielding important information in studying the effects of surface porosity and particle size in many applications.

\section{Cyclic voltammetry analysis}

Cyclic voltammetry is a type of potential dynamic electrochemical measurement. All apparatus for cyclic voltammetry measurement was performed by using Autolab (PGSTAT101) electrochemical workstation under room temperature. The catalyst ink solution was carefully transferred onto the glassy carbon electrode by using micropipette and then leave dried under room temperature. The electrochemical characterization of three types of catalysts was studied by a cyclic voltammetry (CV) test in the potential range -0.7 to $0.4 \mathrm{~V}$ in $50 \mathrm{mV} \mathrm{s}^{-1}$ in $1 \mathrm{M} \mathrm{KOH}$ and at scan rate $50 \mathrm{mVs}^{-}$ ${ }^{1}$ in $0.5 \mathrm{M}$ glycerol/1 M KOH solution. Both solution was de-oxygenated by bubbling with $\mathrm{N}_{2}$ at $200 \mathrm{~mL} \mathrm{~min}^{-1}$ for 30 minutes before taking any measurement of glycerol oxidation reaction.

\section{Results and Discussion}

Phase analysis by X-ray diffraction (XRD) goes beyond elemental composition to characterize the crystalline forms present and understand the alloy structure of bimetallic nanoparticles. Figure 1 showed the XRD patterns of the catalyst samples. The XRD patterns confirmed the presence of target metal in catalyst samples of $\mathrm{Pd} / \mathrm{CNF}, \mathrm{Au} / \mathrm{CNF}$ and $\mathrm{PdAu} / \mathrm{CNF}$ and fit well their characteristic of face centered cubic (fcc) patterns. The $2 \theta$ angle of the diffraction meter was stepped from $20^{\circ}$ to $90^{\circ}$ [18]. The first strong peak for all catalyst samples with value $25.83^{\circ}$ referred to the carbon (002) facet of the carbon nanofiber support. The diffraction peaks in catalyst sample $\mathrm{Pd} / \mathrm{CNF}$ exhibited the characteristic face-centred cubic crystalline structure of Pd-based material with $2 \theta$ values of $39.84^{\circ}, 46.53^{\circ}, 67.53^{\circ}$, and $81.61^{\circ}$ correspond to the (111), (200), (220) and (311) of the metallic palladium face respectively. The diffraction peaks of $\mathrm{Au} / \mathrm{CNF}$ are $38.08^{\circ}, 44.21^{\circ}, 77.80^{\circ}, 65.01^{\circ}$ correspond to the (111), (200), (220) and (311) facets of Au crystals respectively. Meanwhile, for catalyst sample of PdAu/CNF shows that the both metal has form metal alloyed particles since there is only a single peak. The diffraction peak positions for PdAu/CNF, move which located between two wavelengths at each monometallic nanoparticle for Pd and Au. This indicates that, Au has entered Pd lattice and form a homogeneous substitution alloy [19]. 
Norilhamiah et al: PRELIMINARY STUDY ON PD-BASED BINARY CATALYSTS SUPPORTED WITH

CARBON NANOFIBER FOR THE ELECTROOXIDATION OF GLYCEROL

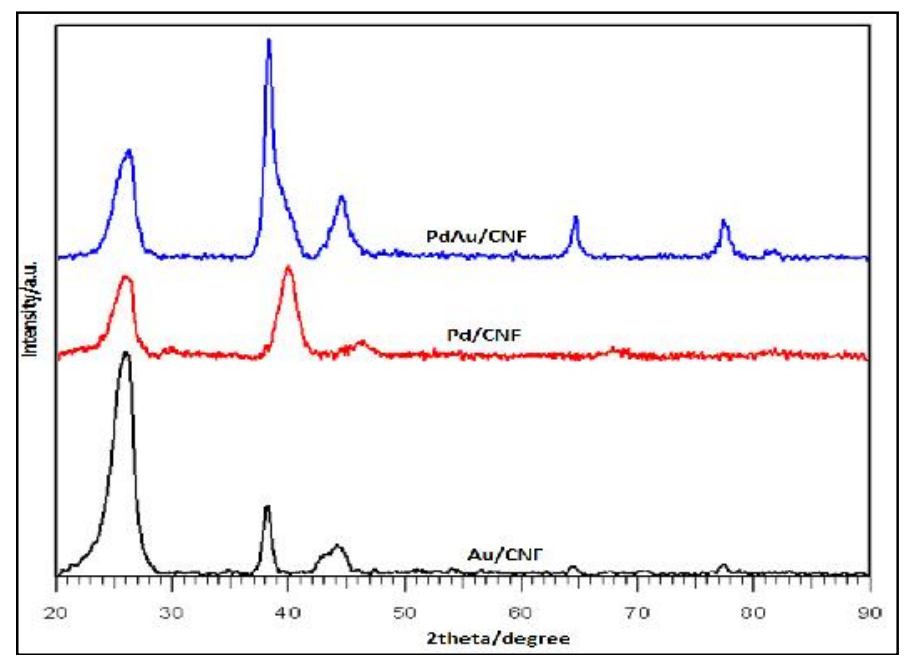

Figure 1. XRD patterns of PdAu/CNF, Au/CNF and Pd/CNF catalysts

BET analysis has been conducted to evaluate the specific area of the catalyst support to ensure the pore of the support has been filled in the catalyst. Specific surface area for CNF before catalyst deposition is $370 \mathrm{~m}^{2} / \mathrm{g}$. Table 1 shows the BET analysis of surface areas for all catalyst samples. From the Table 1 shown that the value of BET has decrease after deposition of catalysts on CNF surface. The metal catalyst has been successfully deposited onto the surface of CNF support. This is due to metal catalyst reduced onto the support and blocks some microspores which leads to a decreased BET surface area.

Table 1. Crystal size, particles size and surface area of the Pd/C, Au/C and PdAu/CNF based on XRD, TEM and BET analysis

\begin{tabular}{lccc}
\hline \multirow{2}{*}{ Catalyst } & XRD & TEM & $\begin{array}{c}\text { BET Surface Area } \\
\left(\mathbf{m}^{2} / \mathbf{g}\right)\end{array}$ \\
\cline { 2 - 3 } & Crystallite Size (nm) & Particle Size $(\mathbf{n m})$ & 24 \\
$\mathrm{Pd} / \mathrm{CNF}$ & 6.0 & 5.7 & 20 \\
$\mathrm{Au} / \mathrm{CNF}$ & 8.7 & 7.5 & 26 \\
$\mathrm{PdAu} / \mathrm{CNF}$ & 4.4 & 4.8 & \\
\hline
\end{tabular}

Figure 2a-c shows the FESEM image of porous structure of the prepared Pd, Au and PdAu supported with carbon nanofiber. The images reveal a three-dimensional image of the catalysts surface and shows the equilibrium forms of small metal crystallites on the dispersed on the support. Meanwhile Figure 3d-f shows the TEM images of Pd/CNF, $\mathrm{Au} / \mathrm{CNF}$ and PdAu/CNF catalyst samples. From TEM images clearly shown that there is no large agglomeration of metal catalysts and supported in CNF. The shape catalysts shown here have ununiformed particle size but still in dimension of nanometre. The determination of activity catalyst not only size dependence as the catalyst size become small so as the surface area for active site become large but the distribution of catalyst on CNF also important. The $\mathrm{CNF}$ as catalyst support help increase in catalyst distribution so that the active site for reaction happen also increase. 

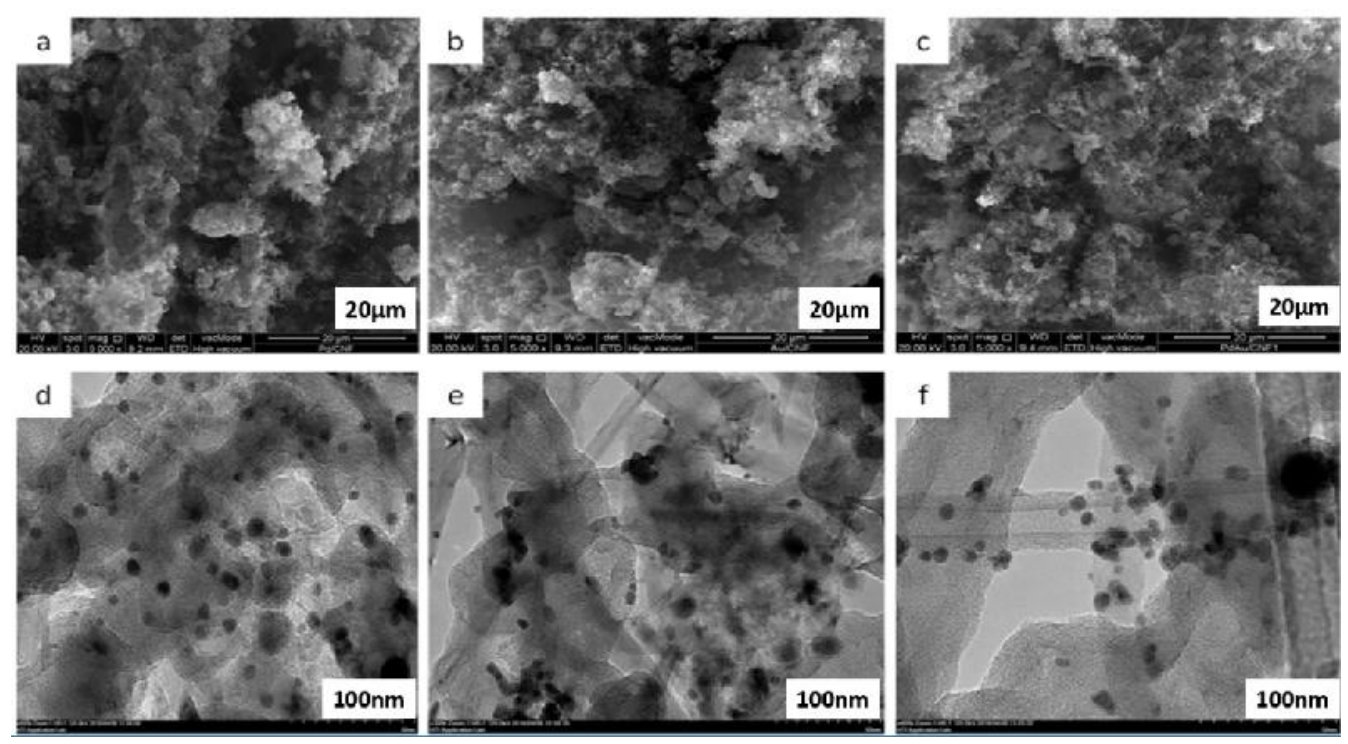

Figure 2. FESEM images of catalysts a) Pd/CNF b) Au/CNF and c) PdAu/CNF. TEM images of d) Pd/CNF, e) $\mathrm{Au} / \mathrm{CNF}$ and f) $\mathrm{PdAu} / \mathrm{CNF}$ catalyst

\section{Electrochemical analysis of cyclic voltammetry}

The performance of catalysts in glycerol oxidation reaction (GOR) was evaluated in terms of two aspects: (1) onset potential $\left(\mathrm{E}_{\text {on }}\right)$; indicative of the catalytic activity over glycerol oxidation reactions, (2) forward anodic specific peak current density ( $\mathrm{I}_{\mathrm{f}}$ ); showing the catalyst maximum performance. To get acquiring qualitative information for catalysts activity in alkaline media, $\mathrm{CV}$ experiment is carried out in $1.0 \mathrm{M} \mathrm{NaOH}$. The CV behaviour of Pd-based catalyst was preliminarily investigated in $1.0 \mathrm{M} \mathrm{KOH}$ without the presence of glycerol as shown in Figure 3. As this analysis is conducted under alkaline environment it can be found that the onset of the oxide formation and the peak potential of the oxide reduction for PdAu/CNF shifted to more negative potentials which exhibit the chemisorption of $\mathrm{OH}$ on the Pd at a negative potential. Glycerol is a complex molecule, due to this the oxidation of glycerol in alkaline medium can form numbers of possible oxide/hydrous or oxide/hydroxyl surface molecules. This is having been described in reduction wave [20]. Based on the previous study the major electrooxidation of glycerol by using Pd catalyst in alkaline media can be described as equation $1-3$ follow [3];

$$
\begin{aligned}
& \mathrm{Pd}+\mathrm{OH}^{-} \leftrightarrow \mathrm{Pd}-(\mathrm{OH})_{\mathrm{ads}}+\mathrm{e}^{-} \\
& \mathrm{Pd}+\mathrm{C}_{2} \mathrm{H}_{3} \mathrm{OH}_{2}-\mathrm{CH}_{2} \mathrm{OH}+3 \mathrm{OH}^{-} \leftrightarrow \mathrm{Pd}-\left(\mathrm{C}_{2} \mathrm{H}_{3}(\mathrm{OH})_{2}-\mathrm{CO}\right)_{\mathrm{ads}}+3 \mathrm{H}_{2} \mathrm{O}+3 \mathrm{e}^{-} \\
& \mathrm{Pd}-(\mathrm{OH})_{\mathrm{ads}}+\mathrm{Pd}-\left(\mathrm{C}_{2} \mathrm{H}_{3}(\mathrm{OH})_{2}-\mathrm{CO}\right)_{\mathrm{ads}} \rightarrow \mathrm{C}_{2} \mathrm{H}_{3}(\mathrm{OH})_{2}-\mathrm{COOH}+2 \mathrm{Pd} \\
& \mathrm{C}_{2} \mathrm{H}_{3}(\mathrm{OH})_{2}-\mathrm{COOH}+\mathrm{OH}^{-} \rightarrow \mathrm{C}_{2} \mathrm{H}_{3}(\mathrm{OH})_{2}-\mathrm{COO}^{-}+\mathrm{H}_{2} \mathrm{O}
\end{aligned}
$$




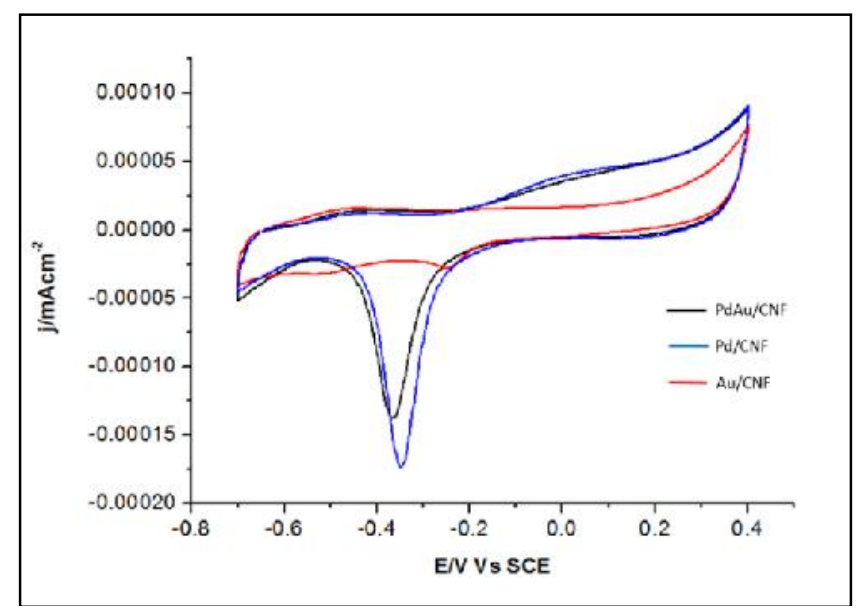

Figure 3. Cyclic voltammogram of $\mathrm{PdAu} / \mathrm{CNF}$ in $1 \mathrm{M} \mathrm{KOH}$ solution at room temperature with the scan rate of 50 $\mathrm{mV} / \mathrm{s}$

Figures 4 shows the $\mathrm{CV}$ scans for $\mathrm{Pd} / \mathrm{CNF}, \mathrm{Au} / \mathrm{CNF}$ and $\mathrm{PdAu} / \mathrm{CNF}$ catalyst for glycerol oxidation in $1.0 \mathrm{M} \mathrm{KOH}$ solution containing $0.5 \mathrm{M}$ glycerol in the potential range $-0.7 \mathrm{~V}$ to $0.4 \mathrm{~V}$. In these $\mathrm{CV}$ scans, a peak is an indication of surface interaction or reaction between some species and catalyst. In the positive-going (forward scan), is attributed to the electrooxidation of glycerol on the catalysts. Meanwhile, during the reverse scan there is a secondary oxidation peak which associated with incomplete oxidation of carbonaceous residues from the glycerol in forward scan. Between three synthesized catalysts, the bimetallic catalyst which is PdAu/CNF shows the best performance towards glycerol oxidation in alkaline media compare with $\mathrm{Pd} / \mathrm{CNF}$ and $\mathrm{Au} / \mathrm{CNF}$ in terms of onset potential and current density. The onset potential $\left(\mathrm{E}_{\text {on }}\right)$ is -0.45 for $\mathrm{Pd} / \mathrm{CNF},-0.46$ for $\mathrm{Au} / \mathrm{CNF}$ and -0.48 for $\mathrm{PdAu} / \mathrm{CNF}$, while the peak current density $\left(\mathrm{I}_{\mathrm{f}}\right)$ for $\mathrm{PdAu} / \mathrm{CNF}$ is $73.81 \mathrm{~mA} \mathrm{~cm}^{-2}$ which is highest compare to $\mathrm{Pd} / \mathrm{CNF}$ and $\mathrm{Au} / \mathrm{CNF}$. The results in forward scan shows that the addition of $\mathrm{Au}$ in Pd form bimetallic catalyst can significantly improve the catalytic activity of Pd for glycerol oxidation in alkaline media.

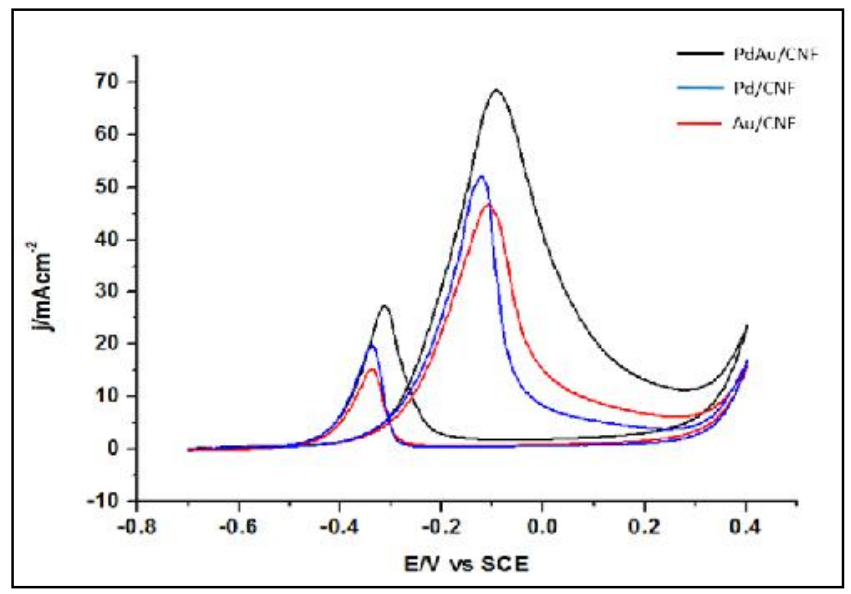

Figure 4. Cyclic voltammograms of $\mathrm{Pd} / \mathrm{CNF}$ and $\mathrm{PdAu} / \mathrm{CNF}$ for the electrooxidation of $0.5 \mathrm{M}$ glycerol using $1.0 \mathrm{M}$ $\mathrm{KOH}$ as an electrolyte scan rate of $50 \mathrm{mV} / \mathrm{s}$ 
The actual performance glycerol oxidation in alkaline media has been summarized in Table 2. Based on Table 2, the onset potential $\left(\mathrm{E}_{\text {on }}\right)$ of glycerol oxidation with $\mathrm{PdAu} / \mathrm{CNF}$ catalyst reveal more negative value compared to $\mathrm{Pd} / \mathrm{CNF}$ and $\mathrm{Au} / \mathrm{CNF}$. This indicates, the significant enhancement oxidation kinetic activity for glycerol by addition of Au. With the addition of Au making the adsorption of oxygen species such as $\mathrm{OH}$ occurs at much lower potential than on monometallic Pd and Au surface to oxidize CO or adsorbed CO-like carbonaceous species on Pd sites. The addition of $\mathrm{Au}$ as second metal in PdAu/CNF also contribute to sufficient oxygen containing species such as $\mathrm{OH}$ to remove the adsorbed carbonaceous species and in other way it will beneficial in oxidation of glycerol [19]. Meanwhile the catalyst poisoning against the carbonaceous species can be traced from the forward scan to backward $\left(\mathrm{I}_{\mathrm{f}} / \mathrm{I}_{\mathrm{r}}\right)$ scan peak current density ratio as shown in Table 2 . The ratio of $\mathrm{PdAu} / \mathrm{CNF}$ catalyst show higher value compare to $\mathrm{Pd} / \mathrm{CNF}$ and $\mathrm{Au} / \mathrm{CNF}$. Therefore PdAu/CNF show better oxidation of methanol to carbon dioxide during anodic scan and less accumulation of carbonaceous species on the catalyst surface compare to Pd/CNF and Au/CNF [21].

Table 2. Electrocatalytic properties Pd/CNF and PdAu /CNF catalysts for glycerol oxidation

\begin{tabular}{|c|c|c|c|c|c|c|c|}
\hline $\begin{array}{l}\text { Catalyst } \\
\text { Types }\end{array}$ & $\begin{array}{c}E_{\text {on }} \\
\text { V vs SCE }\end{array}$ & $\begin{array}{c}E_{p} \\
\text { V vs SCE }\end{array}$ & $\begin{array}{c}\mathbf{I p} \\
\left(\mathbf{m A ~} \mathbf{c m}^{-2}\right)\end{array}$ & $\begin{array}{c}E_{r} \\
\text { V vs SCE }\end{array}$ & $\begin{array}{c}\mathrm{Ir} \\
\left(\mathrm{mA} \mathrm{cm} \mathbf{c m}^{-2}\right)\end{array}$ & $\underset{\left(\mathbf{m A} \mathbf{~ m g}^{-1}\right)}{\mathbf{j}}$ & $\mathbf{I}_{\mathbf{f}} / \mathbf{I}_{\mathbf{B}}$ \\
\hline $\mathrm{Au} / \mathrm{CNF}$ & -0.46 & -0.071 & 55.73 & -0.29 & 23.14 & 371.54 & 2.40 \\
\hline $\mathrm{Pd} / \mathrm{CNF}$ & -0.45 & -0.044 & 63.82 & -0.27 & 40.58 & 425.44 & 1.57 \\
\hline $\mathrm{PdAu} / \mathrm{CNF}$ & -0.48 & -0.091 & 73.81 & -0.32 & 27.94 & 492.04 & 2.64 \\
\hline
\end{tabular}

\section{Chronoamperometric study}

Chronoamperometric study has been employed for 3600 s, where the considerable stability and tolerance to poisoning by intermediates species can be tested. Figure 5 shows the chronoamperometry obtained at room temperature in solutions $1.0 \mathrm{M} \mathrm{NaOH}$ and $0.5 \mathrm{M}$ glycerol for 3600s. For all three catalysts, we can observe a decay of current value in the time interval measured for the studied electrocatalysts. However, after the initial drops the performance become stable for all the catalyst tested. From Figure 6 shows that the PdAu/CNF demonstrates better stability compared to $\mathrm{Pd} / \mathrm{CNF}$ and $\mathrm{Au} / \mathrm{CNF}$ alone, indicating that the present of Au could improve the stability of the catalyst by give a balance adsorption between $\mathrm{OH}$ species from $\mathrm{Au}$ and species from glycerol adsorption on Pd [22].

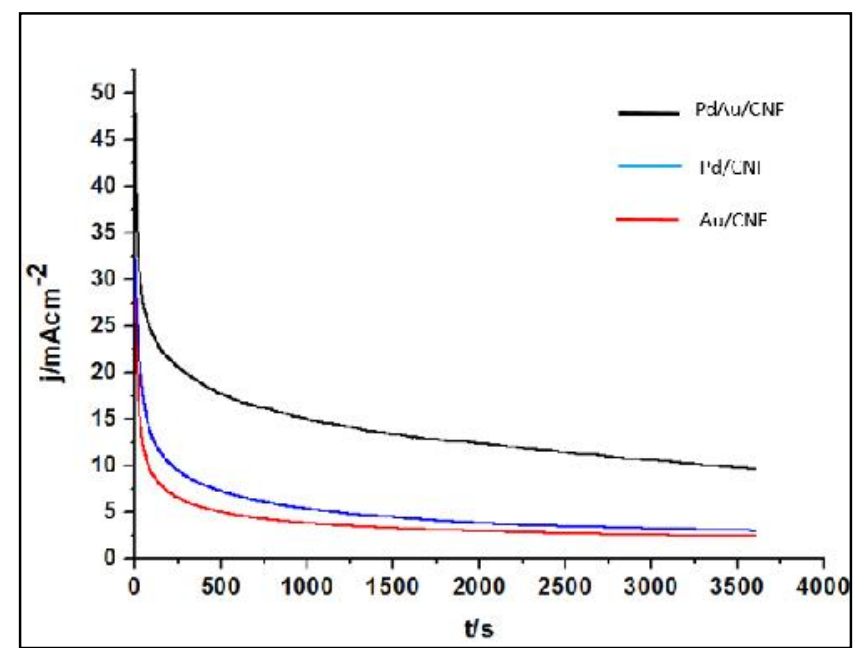

Figure 5. Cyclic voltammograms of $\mathrm{Pd} / \mathrm{CNF}$ and $\mathrm{PdAu} / \mathrm{CNF}$ for the electrooxidation of $0.5 \mathrm{M}$ glycerol using $1.0 \mathrm{M}$ $\mathrm{KOH}$ as an electrolyte 


\section{Conclusion}

In summary, the three types of catalysts namely as Pd/CNF, $\mathrm{Au} / \mathrm{CNF}$ and PdAu/CNF have successfully synthesize by a facile method. XRD data clearly show the presence of Pd, Au and bimetallic PdAu. The FESEM and TEM image shown that the catalysts distributed on supported catalysts of CNF. The CV results exhibited, PdAu/CNF shows excellent catalytic activities and high stability for glycerol oxidation compared to $\mathrm{Pd} / \mathrm{CNF}$ and $\mathrm{Au} / \mathrm{CNF}$. The onset potential of glycerol oxidation for PdAu/CNF more negative than Pd/CNF and Au/CNF which was attributed to the electronic effect. As well as the current density peak for $\mathrm{PdAu} / \mathrm{CNF}$ is higher compared to monometallic catalyst. In addition, the $\mathrm{I}_{\mathrm{f}} / \mathrm{I}_{\mathrm{r}}$ ratio which reflect poisoning species for the oxidation of glycerol shows that bimetallic PdAu/CNF again is higher ratio value which means bimetallic catalyst has higher tolerance to the poisoning species.

\section{References}

1. Li, S. S., Hu, Y. Y., Feng, J. J., Lv, Z. Y., Chen, J. R. and Wang, A. J. (2014). Rapid room-temperature synthesis of Pd nanodendrites on reduced graphene oxide for catalytic oxidation of ethylene glycol and glycerol. International Journal of Hydrogen Energy, 39(8): 3730 - 3738.

2. Habibi, E. and Razmi, H. (2012). Glycerol electrooxidation on Pd, Pt and Au nanoparticles supported on carbon ceramic electrode in alkaline media. International Journal of Hydrogen Energy, 37(22): 16800 -16809.

3. Su, L., Jia, W., Schempf, A. and Lei, Y. (2009). Palladium/titanium dioxide nanofibers for glycerol electrooxidation in alkaline medium. Electrochemistry Communications, 11(11): 2199 - 2202.

4. Kamarudin, M. Z. F., Kamarudin. S. K., Masdar. M. S. and Daud, W. R. W. (2013). Review: Direct ethanol fuel cells. International Journal of Hydrogen Energy, 38(22): 9438 - 9453.

5. Bagheri, S., Julkapli, N. M. and Yehye, W. (2015). Catalytic conversion of biodiesel derived raw glycerol to value added products. Renewable and Sustainable Energy Reviews, 41: 113 - 127.

6. Dector, A., Cuevas-Muñiz, F. M., Guerra-Balcázar, M., Godínez, L. A., Ledesma-García, J. and Arriaga, L. G. (2013). Glycerol oxidation in a microfluidic fuel cell using $\mathrm{Pd} / \mathrm{C}$ and $\mathrm{Pd} / \mathrm{MWCNT}$ anodes electrodes. International Journal of Hydrogen Energy, 38(28): 12617 - 12622.

7. Lee, S., Kim, H. J., Choi, S. M., Seo, M. H. and Kim, W. B. (2012). The promotional effect of Ni on bimetallic $\mathrm{PtNi} / \mathrm{C}$ catalysts for glycerol electrooxidation. Applied Catalysis A: General, 429-430: 39 - 47.

8. Fernández, P. S., Martins, M. E., and Camara, G. A. (2012). New insights about the electro-oxidation of glycerol on platinum nanoparticles supported on multi-walled carbon nanotubes. Electrochimica Acta, 66: 180 - 187.

9. Geraldes, A. N., Da Silva, D. F., e Silva. L. G. D. A., Spinacé, E.V., Neto, A. O., Dos Santos, M. C. (2015). Binary and ternary palladium based electrocatalysts for alkaline direct glycerol fuel cell. Journal of Power Sources, 293: 823 - 830.

10. Rezaei, B., Havakeshian E. and Ensafi A. A. (2014). Fabrication of a porous Pd film on nanoporous stainless steel using galvanic replacement as a novel electrocatalyst/electrode design for glycerol oxidation. Electrochimica Acta, 136: 89 - 96.

11. Zhang, M., Nie, R., Wang L, Shi, J., Du, W. and Hou, Z. (2014). Selective oxidation of glycerol over carbon nanofibers supported Pt catalysts in a base-free aqueous solution. Catalysis Communications, 55: 5 - 9.

12. Maya-Cornejo, J., Arjona, N., Guerra-Balcázar, M., Álvarez-Contreras, L., Ledesma-García, J. and Arriaga, L. G. (2014). Synthesis of Pd-Cu bimetallic electrocatalyst for ethylene glycol and glycerol oxidations in alkaline media. Procedia Chemistry, 12: 19 - 26.

13. Li, S. S., Hu, Y. Y., Feng, J. J., Lv, Z. Y., Chen, J. R. and Wang, A. J. (2014). Rapid room-temperature synthesis of Pd nanodendrites on reduced graphene oxide for catalytic oxidation of ethylene glycol and glycerol. International Journal of Hydrogen Energy, 39(8): 3730 - 3738.

14. Mougenot, M., Caillard, A., Simoes, M., Baranton, S., Coutanceau, C., and Brault, P. (2011). PdAu/C catalysts prepared by plasma sputtering for the electro-oxidation of glycerol. Applied Catalysis B: Environmental, 107(34): 372 - 379.

15. Huang, Z., Zhou, H., Li, C., Zeng, F., Fu, C. and Kuang, Y.(2012). Preparation of well-dispersed PdAu bimetallic nanoparticles on reduced graphene oxide sheets with excellent electrochemical activity for ethanol oxidation in alkaline media. Journal of Material Chemistry A, 22(5):1781 - 1785. 
16. Thi, B., Lam, X., Chiku, M., Higuchi, E. and Inoue, H. (2015). Preparation of PdAg and PdAu nanoparticleloaded carbon black catalysts and their electrocatalytic activity for the glycerol oxidation reaction in alkaline medium. Journal of Power Sources, 297:149 - 157.

17. Feng, Y., Liu, Z., Xu, Y., Wang, P., Wang, W. and Kong, D. (2013). Highly active PdAu alloy catalysts for ethanol electro-oxidation. Journal of Power Sources, 232: 99 - 105.

18. Yang, Z., Liu, L., Wang, A., Yuan, J. and Feng, J. (2016). Simple wet-chemical strategy for large-scaled synthesis of snowflake-like PdAu alloy nanostructures as effective electrocatalysts of ethanol and ethylene glycol oxidation. Internatinal Journal of Hydrogen Energy, 42(4): 2034 - 2044. =

19. Yan, W., Tang, Z., Wang, L., Wang, Q., Yang, H., and Chen, S.(2016). PdAu alloyed clusters supported by carbon nanosheets as efficient electrocatalysts for oxygen reduction. International Journal of Hydrogen Energy, 42(1): $218-227$.

20. Qin, Y-H., Jia, Y-B., Jiang, Y., Niu, D. F., Zhang, X. S., Zhou, X. G., Niu, L. and Yuan, W. K. (2012). Controllable synthesis of carbon nanofiber supported Pd catalyst for formic acid electrooxidation. International Journal of Hydrogen Energy, 37(9): 7373 - 7377.

21. Simões, M., Baranton, S. and Coutanceau, C. (2010). Electro-oxidation of glycerol at Pd based nano-catalysts for an application in alkaline fuel cells for chemicals and energy cogeneration. Applied Catalysis B: Environmental, 93(3-4): 354 - 362.

22. Chen, Z., Wang, S., Lian, C., Liu, Y., Wang, D. and Chen, C. (2016). Nano PdAu bimetallic alloy as an effective catalyst for the Buchwald - Hartwig reaction. Chemistry of Asian Journal, 11(3): 351 - 355. 